\title{
EFFICIENCY OF RESOURCE SAVING AGROTECHNOLOGIES FOR INCREASING COTTON YIELD AND FERTILITY OF MEADOW OF SALTIER SOIL
}

\author{
Sanjar Ernazarovich Ganiev \\ Independent Researcher, Assistant of the Department of Farming and Land Reclamation, \\ Tashkent State Agrarian University, Tashkent, Uzbekistan \\ Komil Muminovich Muminov \\ Professor of the Department of Agriculture, Horticulture and Viticulture, Samarkand Veterinary \\ Medicine Institute, Samarkand, Uzbekistan \\ Nargiza Abdumuratovna Ishdavlatova \\ Independent Researcher, Assistant of the Department Farming and Land Reclamation, \\ Tashkent State Agrarian University, Tashkent, Uzbekistan
}

Article DOI: https://doi.org/10.36713/epra4069

\begin{abstract}
Article considering the productivity of weak and moderately saline meadow soils of the Jizzakh region (Uzbekistan) is estimated at $\mathrm{N}_{160} \mathrm{P}_{80} \mathrm{~K}_{48} \mathrm{~kg} / \mathrm{ha}+$ based on resource-saving agro technologies to produce high-quality cotton (42,3-39,7 $\mathrm{kg} / \mathrm{ha}$ ) under these conditions. Fertilizer consumption of $10 \mathrm{t} / \mathrm{ha}, \mathrm{N}_{160} \mathrm{P}_{112} \mathrm{~K}_{80} \mathrm{~kg} / \mathrm{ha}+20 \mathrm{t} / \mathrm{ha}$ with using of green manure (rape), reducing the level of groundwater and soil salinization, preventing degradation of ponds and soil structure.
\end{abstract}

KEYWORDS: meadow soil, salinity, cotton, fertilizer.

\section{INTRODUCTION}

Nowadays approximately 40 percent of the world's irrigated land is saline, with about 6-7 million acres of salinity. Hectares of land are undergoing degradation and produce about 25 million ha annually. Hectares of land are becoming deserts [11]. The most saline soils in the world are in Argentina - 30,500, in the USA - 5.9, in Egypt - 7.7, in Bulgaria - 3.0, in Hungary - 1.2 thousand and in other arid region countries [10;12].

In Uzbekistan saline soils comprise $48-50 \%$ of the total irrigated area $(4,304,32$ thousand ha), weak saline soils $31,4 \%$, moderate saline soils 15,5 , and highly saline soils $3,8 \%$ [5; 9 ], in low saline areas the yield of cotton decreased by $20-30 \%$, average salinity by $40-60 \%$ and salinity at $60-80 \%$.

Strong influence of salts on cotton cultivating in irrigated area of the Republic is observed at the initial stage of development, during the period of 3-4 leaves. For most cotton varieties, limited salt concentration in the soil is $2.5-3.0 \%$ and after that it will lead to loss of vegetation. The toxic effect of salts on the soil is largely dependent on the ions contained in them. The toxic effect of salts on the soil is largely dependent on the ions containing in them. Chloride salinity is often toxic to cultivar plants on irrigated farmland. Because $0.01 \%$ of their soil content is negatively affecting plants. Toxic effect of sulphates in soils is observed when their content is $0.2-0.3 \%$ [4].

As a result of leaching to improve the reclamation of irrigated arable land, many leaching of nutrients along with harmful salts in the soil was revealed. As a result of soil salinization under different soil-climatic conditions, it was found that $50-70 \%$ of nitrogen content in the soil was reduced to $10-20 \%$ of portable $\left(\mathrm{P}_{2} \mathrm{O}_{5}\right)$ phosphorus and $20-30 \%$ of substitute $\left(\mathrm{K}_{2} \mathrm{O}\right)$ potassium.

The number of beneficial microorganisms in the soil has also decreased significantly [7]. Therefore, effective use of mineral and organic fertilizers and intermediate (green manure) resource-saving innovative technologies is needed to ensure high quality and high yields of these soils and their crops. 


\title{
EPRA International Journal of Research and Development (IJRD)
}

\author{
Volume: 5 | Issue: 2 | February 2020
}

- Peer Reviewed Journal

About $97.5 \%$ of the irrigated land in the Mirzachul district of the Jizzakh region was saline, with slightly saline land $40.2 \%$ of total irrigated land, $32.4 \%$ of the moderately saline soils. In such areas the yield of cotton, winter wheat, maize and other crops is on average decreasing for $20-40 \%[1,8]$.

Therefore, improving the reclamation of irrigated saline land in Jizzakh region, improving soil fertility, developing innovative agro-technologies for preventing groundwater levelsand environmental pollution, is an important issue for further cotton growing in the Republic.

\section{MATERIALS AND METHODS}

In order to investigate the aforementioned issues, we propagate the growth and development of AnBayovut-2 varieties of mineral and organic fertilizers and intermediate crops under saline, weak and moderately saline soils of the Bakhmal AGRO farm in Mirzachul district, Jizzakh region during 2016-2018. Field experiments to determine the impact of soil fertility and salinity in the experiment total area of each delta $(100 \mathrm{~m}$, width 8 rows $\times 0.6=4.8 \mathrm{~m})$ was $480 \mathrm{~m} 2$, including $240 \mathrm{~m} 2$. The variants were sequentially schematically arranged in a single position.

Table 1

System of experiment

\begin{tabular}{|c|c|c|c|c|c|}
\hline \multirow{2}{*}{ Variance, № } & \multicolumn{3}{|c|}{$\begin{array}{c}\text { Annual quantity of nutritional } \\
\text { elements, } \mathbf{k g} / \mathbf{h a}\end{array}$} & $\begin{array}{c}\text { Ratio of fertilizers, } \\
\mathbf{N}: \mathbf{P}: \mathbf{K}\end{array}$ & $\begin{array}{c}\text { green manure } \\
\text { and manure, } \\
\text { t/ha }\end{array}$ \\
\cline { 2 - 4 } & $\mathbf{N}$ & $\mathbf{P}_{\mathbf{2}} \mathbf{0}_{\mathbf{5}}$ & $\mathbf{K}_{\mathbf{2}} \mathbf{0}$ & - & - \\
\hline 1. & - & - & - & $1: 0,7: 0,5$ & - \\
\hline 2. & 240 & 168 & 120 & $1: 0,7: 0,5$ & - \\
\hline 3. & 200 & 140 & 100 & $1: 0,7: 0,5$ & - \\
\hline 4. & 160 & 112 & 80 & $1: 0,7: 0,5$ & 10 \\
\hline 5. & 160 & 112 & 80 & $1: 0,7: 0,5$ & 20 \\
\hline 6. & 160 & 112 & 80 & $1: 0,7: 0,5$ & - \\
\hline 7. & 160 & 112 & 80 & $1: 0,5: 0,3$ & - \\
\hline 8. & 240 & 120 & 72 & $1: 0,5: 0,3$ & greenmanure \\
\hline 9. & 200 & 100 & 60 & $1: 0,5: 0,3$ & greenmanure \\
\hline 10. & 160 & 80 & 48 & $1: 0,5: 0,3$ & 10 \\
\hline 11. & 160 & 80 & 48 & $1: 0,5: 0,3$ & 20 \\
\hline 12. & 160 & 80 & 48 & $1: 0,5: 0,3$ & \\
\hline 13. & 160 & 80 & 80 & & \\
\hline
\end{tabular}

The studies were conducted in the 4 th repetition and the variants (13) were schematically placed in one race.

Nitrogen $(N)$ in field experiments is $-160,200$, 240; studied phosphorus $\left(\mathrm{P}_{2} \mathrm{O}_{5}\right)-112,140,168$ and potassium $\left(\mathrm{K}_{2} \mathrm{O}\right)-80,100,120 \mathrm{~kg} / \mathrm{ha}$, manure (KRS) $10,20 \mathrm{t} / \mathrm{ha}$ and intermediate crops (green manure). In the experiment, $60 \%$ annual phosphorus fertilizer, $50 \%$ potassium, and $100 \%$ fertilizer were submerged, along with the remaining $40 \%$ and $50 \%$ nitrogen fertilizers, with cotton (between 2-4 maple and weeding periods). Intermediate crops (for green manure) were planted rape "Nemerchiniskiy - 2268", Chinese cabbage in the last ten days of September in depth of $2-3 \mathrm{~cm}$ at the rate of $8-10 \mathrm{~kg}$ per hectare and in the third decade of March all blue mass KIR-1.5 and plowed at a depth of $28-32 \mathrm{~cm}$.

\section{RESULTS AND DISCUSSION}

Jizzakh region is one of those regions that have the most acute problems, including the decline in the quantity and quality of surface and underground water resources, and the deterioration of the reclamation of irrigated lands. The region produces cotton, wheat, fruits and vegetables and melons.

The sedimentary soils under study have loamy sands and loams of dealluvial - prolluvial genesis and according to the mechanical composition, the soil is heavy and medium sandy with loamy sandy and sandy loam layers below the soil. Deposition of different mineralized ground waters to the surface $(1.5-2.0 \mathrm{~m})$ accelerates the salinization process, which results in soil salinization. Depending on the salinity, these soils are weak, moderate and highly saline, with the salinity type of chloride-sulphate and sulphate-chloride salinization.

The aim of this study is improving the reclamation of saline soils of Jizzakh region with the use of field and laboratory experiments, to prevent soil erosion and salinization, increasing soil fertility, maintain a clean environment, producing high quality cotton and mineral fertilizers, determining the effects of organic fertilizers and intermediate crops (green manure) and develop a scientifically-grounded approach to the efficient use of irrigated land for production pensions guarantees. 


\title{
EPRA International Journal of Research and Development (IJRD)
}

\author{
Volume: 5 | Issue: 2 | February 2020
}

- Peer Reviewed Journal

At the beginning of the vegetation period (before sowing) amount of dry residue in the $0-70 \mathrm{~cm}$ layer of saline grassland is 0,225 and chloride ion is 0.012 ; sulphate $0.098 \%$, and in $0-100 \mathrm{~cm}$ layers 0,239 respectively; $0.015 ; 0.107 \%$, the salinity of weak saline fields is $0-70 \mathrm{~cm}$ dry residue $-0.251 ; 0.016$; At $0.114 \%$, these figures are 0.266 in the $0-70 \mathrm{~cm}$ layer of the average saline field; $0.017 ; 0.121 \%$ and $0,200 \mathrm{~cm}$ respectively 0,$257 ; 0.018 ; 0.129 \%$.

Should be noted that increased saline soils $(27 \%)$ at the depths of $35-53 \mathrm{~cm}$, with weak saline soils (30\%), in this saline area is $43 \%$. These figures indicate that the land will be salinized immediately unless reclamation measures are carried out in these areas.

According to the results of phenological observations development of AN-Bayovut-2 type of cotton under saline, weak and moderately saline soils, the plant height under influencing fertilizers $\left(\mathrm{N}_{160} \mathrm{P}_{112} \mathrm{~K}_{80} \mathrm{~kg} / \mathrm{ha}\right)$ is $81.6 ; 76.3 ; 69,7 \mathrm{~cm}$, the number of branches is 9,$6 ; 9.1 ; 8.2$ and $7.8 ; 7.0 \mathrm{~cm}$; In variants used amount of fertilizers $\left(\mathrm{N}_{200} \mathrm{P}_{140} \mathrm{~K}_{100} \mathrm{~kg} / \mathrm{ha}\right)$ this indicator was $87.2 ; 82.5 ; 76.7 \mathrm{~cm}, 10.5 ; 9.8 ; 9.1$ and 8.7 ; 8.2; 7.7 grains, in the variants given fertilizer $\left(\mathrm{N}_{240} \mathrm{P}_{168} \mathrm{~K}_{120} \mathrm{~kg} / \mathrm{ha}\right)$, the height of stem of the plant was $91.4 ; 87.6 ; 80.2 \mathrm{~cm}, 11.6 ; 10.4 ; 9.7$ and $9.3 ; 8.6 ; 8.0 \mathrm{~cm}$.

In the saline field, fertilizers in $\mathrm{N}_{160} \mathrm{P}_{80} \mathrm{~K}_{48} \mathrm{~kg} / \mathrm{ha}$ are used in the background of fertilizer and green manure at a rate of $10.20 \mathrm{t} / \mathrm{ha} .78 .3 ; 80.5 \mathrm{~cm}$, yield branches $8.3 ; 9.2 ; 9.4$ and number of headings $6.9 ; 7.7$; 8.1 units, with an average salinity of $69.5 ; 74.6 ; 78.2$ $\mathrm{cm}, 7.8 ; 8.7 ; 9.1$ and $6.5 ; 7.2$; It was found at 7.9 units. In the experimental field, the number of cotton, nonfertilized (control) cotton, the number of branches and weeds on August 1, in the ratio of fertilizers (1: 0.5: 0.3; 1: $0.7: 0.5$ ) or $10.20 \mathrm{t} / \mathrm{ha}$, it was found to be much lower than that used on the background of manure and green manure. High salinity and yield of cotton grown in these areas under the influence of fertilizer $\mathrm{N}_{160} \mathrm{P}_{80} \mathrm{~K}_{48} \mathrm{~kg} / \mathrm{ha}$ fertilizer in moderately saline soils with moderate salinity at $\mathrm{N}_{160} \mathrm{P}_{112} \mathrm{~K}_{80} \mathrm{~kg} / \mathrm{ha}$ of fertilizer and green manure or, this difference was found to be $6.7-9.3 \mathrm{~cm}$, 1.6-2.3, and 1.3-1.9, relative to the height of the saline field and the number of crops and shoots.

In the non-fertilized (control) variants of saline, weak and moderately saline areas of the experimental field, yield was 16.2; 15.3; and $13.6 \mathrm{c} / \mathrm{ha}$ (centner/hectare).

In the saline, weak and moderately saline fields, the fertilizer yield is $31.4 ; 29.6 ; 26.8 \mathrm{c} / \mathrm{ha}$, fertilizer variants $\mathrm{N}_{200} \mathrm{P}_{100} \mathrm{~K}_{60}$ and $\mathrm{N}_{240} \mathrm{P}_{120} \mathrm{~K}_{72} \mathrm{~kg} /$ ha yields 36.5 $39.3 ; 33.7-35,4$; At $30,8-33,2 \mathrm{t} / \mathrm{ha}$, the fertilizer ratio is reduced by the nutritional elements contained in manure, which is proportional to the crop yield of $\mathrm{N}_{160} \mathrm{P}_{80} \mathrm{~K}_{48} \mathrm{~kg} /$ ha amount of $10.20 \mathrm{t} /$ ha against fertilizer and green manure determined cotton yield with 34,6 ; $32.4 ; 31.8$ - 39.7; $36.3 ; 35.5$ and $42.3 ; 38.7 ; 36.8 \mathrm{c} / \mathrm{ha}$.
Growth and development of cotton, when applied on $\mathrm{N}_{240} \mathrm{P}_{120} \mathrm{~K}_{72} \mathrm{~kg} / \mathrm{ha}, \mathrm{N}_{160} \mathrm{P}_{80} \mathrm{~K}_{48} \mathrm{~kg} / \mathrm{ha}+10 \mathrm{t} / \mathrm{ha}$ fertilizer, or green manure on saline, weak and moderately saline grassy soils optimum conditions for harvesting are $9.8 \mathrm{c} / \mathrm{ha}$, respectively, compared to the cotton yield in the areas where the recommended fertilizer $\left(\mathrm{N}_{200} \mathrm{P}_{140} \mathrm{~K}_{100} \mathrm{~kg} / \mathrm{ha}\right)$ is applied $8.2 \mathrm{c} / \mathrm{ha}$; It was found that an additional $7.6 \mathrm{t} / \mathrm{ha}$ provided good quality yields.

\section{CONCLUSION}

In spite of water - physic and agrochemical features of middle salinity and weak salinity soils of gray - grassland of Jizzakh region, using mineral fertilizers and green manures considering producing cotton plant with high yield and high quality of cotton fiber as like producing this kind of plant in normal condition without salinification (39,7-42,3 c/ha).

Increasing productivity of weak and moderately saline meadow soils of Mirzachul using proportional agro technology to obtain high-quality cotton from the cotton grown under these conditions and fertilizer proportionally at $\mathrm{N}_{160} \mathrm{P}_{80} \mathrm{~K}_{48} \mathrm{~kg} / \mathrm{ha}+10 \mathrm{t} / \mathrm{ha}+20 \mathrm{t} / \mathrm{ha}+$ $20 \mathrm{t} / \mathrm{ha}$ It was found that their application in the background of siderites provides high economic efficiency under these conditions and reduces groundwater levels and soil salinization and prevents the degradation of ponds and soil ecology.

\section{REFERENCES}

1. Akmedov I., Mirkhosilova Z. (2013). Factors of soil salinization and decrease in productivity. Agriculture of Uzbekistan. - Tashkent, №10 pp. 3132.

2. Methods of field experiments. - Tashkent: UzCGRI, 2007. 145 p.

3. Dospekhov B.A. (1985). The methodology of field experience, -M: Agropromizdat, $350 \mathrm{p}$.

4. Jabborov O., Makhkamova D. (2018). Salinity of irrigated land in Vobkent district of Bukhara region. "Soil, climate, fertilizers and crops: current problems and prospects". Republic scientific practice conference. dedicated to 100th anniversary of NUU. - M., NUU, 2018 .-- pp. 190-194.

5. Kulmatov R. (2018). Sustainable Development indicators of lower Zarafchon region and their practical evaluation (Uzbekistan). LAP Lambert Academic Publishing, Germany, 110 pp.

6. Methods of agrochemical, agrophysical and microbiological studies in irrigated cotton areas. Tashkent. 1963. $460 \mathrm{p}$.

7. Mirzajonov Q., Isaev S. (2014). What is the land reclamation condition?. Agroilm. Tashkent, No.4(32). pp. 60-62.

8. Sattarov J., Atoev B. (2018). Investigation of the condition of salt-washed soils, development of agrotechnology for their reproduction and increase. International science. tex. conf material. Tashkent: UzMU. pp. 73-78. 
9. National report on the state of land resources of the Republic of Uzbekistan. - Tashkent. 2018. 73 p.

10. Shakirov N. (2016). Measures to prevent degradation of irrigated land and pasture. Responses to the topic "Issues of protection and rational use of land resources in the context of environmental change". science. action seminar lecture balls. Tashkent: UzMU, pp. 23-25.

11. Food and Agriculture Microdata Catalogue (FAM), http://www.fao.org/food-agriculture-microdata/en/ 